\title{
A CHOICE OF CRITICAL SECTIONS OF ELECTRIC WIRES AND CABLES IN POWER CIRCUITS OF ELECTRICAL EQUIPMENT OF POWER INDUSTRY
}

Purpose. Implementation of close calculation determination of critical sections of $S_{C i}$ and critical amplitudes of density of alternating current $\delta_{C i}$ of frequency $50 \mathrm{~Hz}$ in wires and cables of power circuits of electrical equipment of power industry, characterized flowing in it at malfunctions of operation current $i_{k}(t)$ of short circuit (SC) with set amplitude-temporal parameters (ATP). Methodology. Scientific and technical bases of power engineering, electrophysics bases of technique of high-voltage and large pulsed currents, theoretical bases of the electrical engineering. Results. The results of the developed electrical engineering approach are resulted in a calculation choice on the condition of electric explosion (EE) of current-carrying parts of cable and conductor products (CCP) of critical sections of $S_{C_{i}}$ for the copper (aluminum) cores of the uninsulated wires, and also for the insulated wires and cables with a polyvinilkhloride (PVC), rubber (R) and polyethylene (PET) insulation with copper (aluminum) cores (shells) on which in the power circuits of electrical equipment of the general industrial equipment in malfunction the current of SC $i_{k}(t)$ flows with set ATP. On the basis of determination of sizes of the real critical sections $S_{C i}$ for the indicated wires and cables the calculation numeral estimation of critical amplitudes of density $\delta_{C i}$ of $S C$ current $i_{k}(t)$ is executed with set ATP in current-carrying parts of investigated CCP of power circuits of the examined electrical equipment. It is determined that in the power circuits of electric equipment of the general industrial installations (for permanent time of slump of $T_{a}=50 \mathrm{~ms}$ of aperiodic to the constituent of current of SC) critical amplitudes of density $\delta_{C i}$ of $S C$ current $i_{k}(t)$ at time of his disconnecting $t_{k}=100 \mathrm{~ms}$ in copper (aluminum) cores for the uninsulated wires and insulated wires (cables) with copper (aluminum) cores (shells), PVH, $R$ and PET it is numeral made an insulation according to approximately $1,57(1,18) \mathrm{kA} / \mathrm{mm}^{2}$. At time of disconnecting $t_{k}=160 \mathrm{~ms}$ of $S C$ current $i_{k}(t)$ in the power circuits of the examined electrical equipment $\left(T_{a}=50 \mathrm{~ms}\right.$ ) critical amplitudes of density $\delta_{C i}$ of $S C$ current $i_{k}(t)$ for the copper (aluminum) cores (shells) of indicated CCP become accordingly numeral equal approximately $1,33(0,99) \mathrm{kA} / \mathrm{mm}^{2}$. Originality. First by a calculation way taking into account information for ATP of SC current $i_{k}(t)$ and quantitative values of time of his disconnecting $t_{k}$ in the power circuits of electrical equipment of the general industrial installations the numerical values of critical sections $S_{C i}$ and critical amplitudes of density $\delta_{C i}$ of $A C S C$ current $i_{k}(t)$ are certain for the uninsulated wires, and also insulated wires and cables with copper (aluminum) cores (shells), PVH, $R$ and PET insulation. Practical value. Obtained results for the critical sections $S_{C i}$ and amplitudes of density $\delta_{C i}$ of $A C S C$ current $i_{k}(t)$ of frequency $50 \mathrm{~Hz}$ (at the period of oscillations of $T_{p}=20 \mathrm{~ms}$ for of periodic constituent of emergency current of $S C$ ) can be utilized in power industry in practice at a choice thermally by a bar to the action of large SC currents $i_{k}(t)$ of CCP with copper (aluminum) bars (shells), intended for reliable operation in the power circuits of electrical equipment of industrial power industry. References 8 , tables 5.

Key words: power industrial, electrical equipment, electric wires and cables of circuits of electrical equipment, calculation choice of critical sections of wires and cables in the circuits of electrical equipment.

Надані результати розробленого електротехнічного підходу до розрахункового вибору по умові електричного вибуху (ЕВ) струмопровідних частин кабельно-провідникової продукції критичних перерізів $S_{C i}$ неізольованих дротів, а також ізольованих дротів і кабелів з полівінілхлоридною (ПВХ), гумовою (Г) $\boldsymbol{i}$ поліетиленовою (ПЕТ) ізоляцією 3 мідними (алюмінісвими) жсилами (оболонками), по яких в силових колах електрообладнання загальнопромислового призначення в аварійному режимі протікає струм $i_{k}(t)$ короткого замикання (К3) із заданими амплітудно-часовими

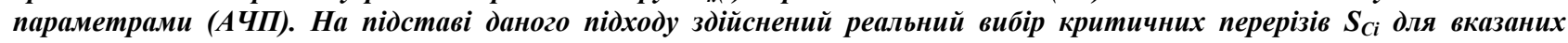
дротів (кабелів) силових кіл електрообладнання, щчо розглядається. Виконана розрахункова чисельна оцінка критичних амплітуд щңільностей $\delta_{C i}$ струму $i_{k}(t)$ КЗ із заданими АЧП в дротах $i$ кабелях силових кіл вказаного електрообладнання. Отримані дані сприятимуть забезпеченню термічної стійкості електричних неізольованих дротів, а також дротів $i$ кабелів з ПВХ, Г $і$ ПЕТ ізоляцією, які широко застосовуються в силових колах електрообладнання загальнопромислового призначення. Бібл. 8, табл. 5.

Ключові слова: промислова електроенергетика, електрообладнання, електричні дроти і кабелі кіл електрообладнання, розрахунковий вибір критичних перерізів дротів і кабелів в колах електрообладнання.

Приведены результаты разработанного электротехнического подхода к расчетному выбору по условию электрического взрыва (ЭВ) токонесущих частей кабельно-проводниковой продукции критических сечений $S_{C i}$ неизолированных проводов, а также изолированных проводов и кабелей с поливинилхлоридной (ПВХ), резиновой (P) и полиэтиленовой (ПЭТ) изоляцией с медными (алюминиевыми) жсилами (оболочками), по которым в силовых цепях электрооборудования общепромышленного назначения в аварийном режиме протекает ток $i_{k}(t)$ короткого замыкания (КЗ) с заданными амплитудно-временными параметрами (АВП). На основании данного подхода осуществлен реальный выбор критических сечений $S_{C i}$ для указанных проводов (кабелей) силовых цепей рассматриваемого электрооборудования. Выполнена расчетная численная оценка критических амплитуд плотностей $\delta_{C i}$ тока $i_{k}(t) K^{3}$ заданными АВП в проводах и кабелях силовых цепей указанного электрооборудования. Полученные данные будут способствовать обеспечению термической стойкости электрических неизолированных проводов, а такэже проводов и кабелей с ПВХ, Р и ПЭТ изоляцией, широко применяемых в силовых цепях электрооборудования общепромышленного назначения. Библ. 8 , табл. 5 .

Ключевые слова: промышленная электроэнергетика, электрооборудование, электрические провода и кабели цепей электрооборудования, расчетный выбор критических сечений проводов и кабелей в цепях электрооборудования.

Introduction. In [1] the results of a calculation and experimental determination of critical sections $S_{C i}$ and critical amplitudes of current densities $\delta_{C i}$ for non- and insulated electric wires (cables) containing metal cores $(i=1)$ and shells $(i=2)$ and used in discharge circuits of high-voltage high-current pulse technology are presented. The basis for this choice of $S_{C i}$ cross-sectional values of 
conductive wires (shells) and current density amplitudes $\delta_{C i}$ for cable-conductor products $(\mathrm{CCP})$ with pulsed axial current varying in the nano-, micro-, and millisecond time ranges was known in electrophysics the electric explosion (EE) condition $[2,3]$ of metal cores (shells) of the indicated wires and cables, leading to the sublimation of their current-carrying parts and the CCP failure. In the field of power industry in emergency operation of the power circuits of its electrical equipment, accompanied by the flow of short-circuit (SC) current $i_{k}(t)$ through the currentcarrying parts of the CCP with frequency $f=50 \mathrm{~Hz}$ and amplitude of up to (40-125) kA [4], at unreasonable use in the power circuits of the electric equipment of the CCP, cases of the occurrence of the EE phenomenon of copper (aluminum) cores and shells (reverse conductors) of their wires and cables are also possible. Insufficient attention was paid by electrical engineers and power engineers to such emergency conditions in power circuits of electrical equipment of general industrial use with similar dire consequences for their CCP. In this regard, the calculation determination of the critical cross-sections $S_{C i}$ of electric wires (cables) used in power circuits of electrical equipment of general industrial use is an urgent applied problem in the field of power engineering.

The goal of the paper is to perform an approximate calculation determination of critical sections $S_{C i}$ and critical amplitudes of densities $\delta_{C i}$ of AC current with frequency $f=50 \mathrm{~Hz}$ in the wires and cables of power circuits of electrical equipment of power industry, characterized by flowing in them in emergency modes of SC current $i_{k}(t)$ with specified amplitude-temporal parameters (ATPs).

1. Problem definition. Let us consider widely used in power circuits of electrical equipment of general industrial use uninsulated copper and aluminum wires, as well as insulated wires and cables with copper (aluminum) inner cores and outer shells-current conductors with the initial specific conductivity $\gamma_{0 i}$ of their non-magnetic material, having polyvinyl chloride (PVC), rubber (R) and polyethylene (PET) belt insulation $[4,5]$. We assume that along round continuous or split copper (aluminum) cores (shells) of the indicated wires and cables of power electric circuits of the considered electrical equipment in emergency mode in their longitudinal direction current $i_{k}(t)$ of the three-phase SC with specified ATPs flows. We indicate that this particular type of SC current is the calculated emergency current for the electrical equipment under study [4]. We believe that the wires and cables under consideration are located in an ambient air environment, the temperature of which corresponds to room temperature and is equal to $\theta_{0}=20{ }^{\circ} \mathrm{C}[2,4]$. The above value of the specific conductivity $\gamma_{0 i}$ of the core (shell) material of the CCP corresponds to this temperature. We believe that the wires (cables) under consideration, before exposure to their current-carrying parts of the SC current $i_{k}(t)$ with specified ATPs, can be both de-energized and under nominal current load. In this regard, the initial temperature $\theta_{0 i}$ of the material of the current-carrying parts of the CCP, depending on the current mode of operation of the power circuits of the electrical equipment, can correspond to $\theta_{0}=20^{\circ} \mathrm{C}$ or the value of the long-term allowable heating temperature $\theta_{l i}$ of their material. It is known that for non- and insulated wires and cables with PVC, R and PET insulation, the temperature $\theta_{l i}$ does not numerically exceed the levels of 70 and $65^{\circ} \mathrm{C}$ regulated by current requirements, respectively $[4,6]$. We use the assumption that the axial SC current $i_{k}(t)$ is almost uniformly distributed over the cross-section $S_{i}$ of the core (shell) of the wire (cable) of the electrical equipment considered. The justification for this assumption is that the minimum penetration depth $\Delta_{i}$ of the magnetic field (skin layer thickness) from the SC current ${ }_{k}(t)$ in the quasi-stationary approximation into the considered nonmagnetic conductive materials, determined from the calculated relation of the form $\Delta_{i} \approx\left[1 /\left(\pi f \mu_{0} \gamma_{0 i}\right)\right]^{1 / 2}[2]$, where $\gamma_{0 i}$ is the electrical conductance of the core (shell) material of the CCP at $\theta_{0}=20{ }^{\circ} \mathrm{C}$, and $\mu_{0}=4 \pi \cdot 10^{-7} \mathrm{H} / \mathrm{m}$ is the magnetic constant, numerically for copper is approximately $9.3 \mathrm{~mm}$, and for aluminum is $11.8 \mathrm{~mm}$. It can be seen that the presented numerical values of $\Delta_{i}$ are comparable with the real radii (thicknesses) of the current-carrying conductors (shells) of wires and cables used in electrical equipment circuits of general industrial use. We use the condition of the adiabatic nature of the occurring at times of action of the SC current $i_{k}(t)$ in the power circuits of the specified electrical equipment of no more than $1000 \mathrm{~ms}$ in the materials of the conductors (shells) of the investigated CCP of the electrothermal processes under which heat transfer from surfaces of current-carrying parts having the current temperature $\theta_{C i} \geq \theta_{0 i}$, and the thermal conductivity of the layers of its conductive materials of the core (shell) and insulation on the Joule heating of the current-carrying parts of the checkpoint are neglected. It is required by calculation to determine in approximate form the critical sections $S_{C i}$ of current-carrying parts for uninsulated copper (aluminum) wires, as well as for insulated wires and cables with copper (aluminum) cores (shells), PVC, R and PET insulation used in power circuits of electrical equipment of general industrial applications and experiencing in emergency operation mode the direct effect of the axial SC current i $i_{k}(t)$ with specified ATPs. In addition, based on the calculation of the values of the critical sections $S_{C i}$, it is necessary to determine the values of the critical amplitudes of the densities $\delta_{C i}$ of $\mathrm{AC}$ current with frequency $f=50 \mathrm{~Hz}$ in the current-carrying parts of wires and cables of power circuits of electrical equipment of power industry, through which SC current $i_{k}(t)$ can flow.

The electrical engineering approach to the calculation of critical sections $S_{C i}$ and current densities $\delta_{C i}$ in wires and cables of circuits of electrical equipment for general industrial purposes. To find critical cross-sections $S_{C i}$ of conductive cores (shells) of considered non-insulated and insulated with PVC, R and PET insulation electrical wires and cables in power circuits of electrical equipment with axial SC current $i_{k}(t)$ of specified ATPs, from the equation of their heat balance in the adiabatic Joule mode heating of the currentcarrying parts of the CCP the following calculation relation follows [3]:

$$
S_{C i}=\left(J_{C i A}\right)^{1 / 2} / D_{C i}
$$


where $J_{C i A}=\int_{0}^{t_{k}} i_{k}^{2}(t) d t-$ the Joule (action) integral for the SC current $i_{k}(t)$ with duration $t_{k}$ of its flow through the cores (shells) of the CCP, A $\mathrm{A}^{2} \cdot \mathrm{s} ; \quad D_{C i}=\left(J_{C i}-J_{l i}\right)^{1 / 2}$, $\mathrm{A} \cdot \mathrm{s}^{1 / 2} / \mathrm{m}^{2} ; J_{l i}$ is the critical value of the current integral for the material of cores (shells) of wires and cables of electrical equipment circuits [2], $\mathrm{A}^{2} \cdot \mathrm{s} / \mathrm{m}^{4} ; J_{l i}$ is the value of the current integral for the material of conductors (shells) of wires and cables of electrical equipment circuits, the long-term permissible heating temperature of which with the rated current corresponds to the known value $\theta_{l i}[4], \mathrm{A}^{2} \cdot \mathrm{s} / \mathrm{m}^{4}$.

In (1), the value of the current integral $J_{l i}$ is calculated from the following analytical expression [3]:

$$
J_{l i}=\gamma_{0 i} \beta_{0 i}^{-1} \ln \left[c_{0 i} \beta_{0 i}\left(\theta_{l i}-\theta_{0}\right)+1\right],
$$

where $c_{0 i}, \beta_{0 i}$ are accordingly, the specific heat attributed to the unit volume of the material of the core (shell) of the wire (cable) and the thermal coefficient of the specific conductivity of this $\mathrm{CCP}$ material before the SC current $i_{k}(t)$ flows through it at $\theta_{0}=20^{\circ} \mathrm{C}$.

It can be seen from (2) that at $\theta_{l i}=\theta_{0}$ (the power-off mode of the CCP), the desired current integral is zeroed $\left(J_{l i}=0\right)$.

In Table 1 at $\theta_{0}=20{ }^{\circ} \mathrm{C}$, numerical values are given for such basic characteristics of copper and aluminum conductors (shells) of wires (cables) of the studied power circuits as $\gamma_{0 i}, c_{0 i}, \beta_{0 i}$ and $J_{C i}[2]$.

Table 1

Thermophysical characteristics of copper (aluminum) cores (shells) of considered wires and cables of power circuits of electrical equipment before action on them of SC current

$$
i_{k}(t)\left(\text { at } \theta_{0}=20{ }^{\circ} \mathrm{C}\right)[2]
$$

\begin{tabular}{|c|c|c|c|c|}
\hline \multirow{2}{*}{$\begin{array}{l}\text { Material of the } \\
\text { core (shell) of } \\
\text { the wire (cable) }\end{array}$} & \multicolumn{4}{|c|}{ Numerical value of the characteristic } \\
\hline & $\begin{array}{l}\gamma_{0 i}, 10^{7} \\
(\Omega \cdot \mathrm{m})^{-1}\end{array}$ & $\begin{array}{c}c_{0 i}, 10^{6} \cdot \mathrm{J} / \\
\left(\mathrm{m}^{3} \cdot{ }^{\circ} \mathrm{C}\right)\end{array}$ & $\begin{array}{c}\beta_{0 i}, 10^{-9} . \\
\mathrm{m}^{3} / \mathrm{J}\end{array}$ & $\begin{array}{l}J_{C i}, 10^{17} \\
\mathrm{~A}^{2} \cdot \mathrm{s} \cdot \mathrm{m}^{-4}\end{array}$ \\
\hline Copper & 5.81 & 3.92 & 1.31 & 1.95 \\
\hline Aluminum & 3.61 & 2.70 & 2.14 & 1.09 \\
\hline
\end{tabular}

Table 2, taking into account the use of data of (1), (2) and Table 1, shows the numerical values of the coefficient $D_{C i}$ necessary for calculating, according to (1), the critical cross-section $S_{C i}$ of the conductive core (sheath) of the considered wire (cable) in the power circuit of electrical equipment used in power industry.

Table 2

Numerical values of the coefficient $D_{C i}$ for non- and insulated wires (cables) with copper (aluminum) cores (shells) in generalpurpose electrical equipment circuits

\begin{tabular}{|c|c|c|c|}
\hline \multirow{2}{*}{$\begin{array}{c}\text { Type of insulation in } \\
\text { the wire (cable) of the } \\
\text { electrical installation }\end{array}$} & $\begin{array}{c}\text { Material of the core } \\
\text { (shell) of the wire } \\
\text { (cable) }\end{array}$ & \multicolumn{2}{|c|}{$\begin{array}{c}\text { Numerical } \\
\text { value of } D_{C i}, \\
10^{8} \mathrm{~A} \cdot \mathrm{s}^{1 / 2} / \mathrm{m}^{2}\end{array}$} \\
\cline { 2 - 4 } & $J_{l i} \neq 0$ & $J_{l i}=0$ \\
\hline \multirow{2}{*}{ Without insulation } & Copper & 4.299 & 4.415 \\
\cline { 2 - 4 } & Aluminum & 3.236 & 3.301 \\
\hline \multirow{2}{*}{ PVC, R } & Copper & 4.299 & 4.415 \\
\cline { 2 - 4 } & Aluminum & 3.236 & 3.301 \\
\hline \multirow{2}{*}{ PET } & Copper & 4.299 & 4.415 \\
\cline { 2 - 4 } & Aluminum & 3.236 & 3.301 \\
\hline
\end{tabular}

From the data of Table 2 it can be seen that the current mode of operation of the CCP under consideration (wires and cables of electrical circuits are fully loaded with rated current $\left(J_{l i} \neq 0\right)$ or at $J_{l i}=0$ are completely deenergized) slightly affects the numerical values of the calculated coefficient $D_{C i}$ (up to $3 \%$ ). Its quantitative values are determined mainly by the type of conductive material of the core (shell) of the considered CCP. For copper and aluminum, the difference in the numerical values of $D_{C i}$ is approximately $25 \%$.

It follows from (1) that, for the numerical values of the coefficient $D_{C i}$ found (see Table 2), the determination of the critical cross-sections $S_{C i}$ of the copper (aluminum) cores (shells) of the investigated CCP is reduced to the quantitative determination of the action integral $J_{C i A}$ of the SC current $i_{k}(t)$ flowing during time $t_{k}$ over the currentcarrying parts of the selected wires and cables.

2.1 Approximate calculation at $\mathrm{SC}$ integral of the action integral $\boldsymbol{J}_{C i A}$ of the emergency current. As in $[7,8]$, we assume that the SC current $i_{k}(t)$ in the circuits with the considered CCP is described by the following temporal dependence:

$$
i_{k}(t)=I_{m k}\left[\exp \left(-t / T_{a}\right)-\cos \left(2 \pi t / T_{p}\right)\right]
$$

where $I_{m k}$ is the amplitude of the steady SC current $i_{k}(t)$ in the power circuit of the electrical equipment; $T_{a}, T_{p}$ are, respectively, the decay time constant of the aperiodic component and the period of oscillations of the periodic component of the emergency SC current $i_{k}(t)$ in the circuit with the CCP.

Then, based on (1) and (3), the calculated expression for the integral of the action of the SC current $i_{k}(t)$ in power circuits with the CCP takes the following analytical form [7]:

$$
\begin{aligned}
& J_{C i A}=I_{m k}^{2}\left\{0,5 t_{k}+0,25 \pi^{-1} T_{p} \sin \left(2 \pi t_{k} / T_{p}\right) \times\right. \\
& \times \cos \left(2 \pi t_{k} / T_{p}\right)-2 T_{a}^{2} T_{p}^{2}\left(T_{p}^{2}+4 \pi^{2} T_{a}^{2}\right)^{-1}\left[\exp \left(-t_{k} / T_{a}\right) \times\right. \\
& \left.\times\left[2 \pi T_{p}^{-1} \sin \left(2 \pi t_{k} / T_{p}\right)-T_{a}^{-1} \cos \left(2 \pi t_{k} / T_{p}\right)+T_{a}^{-1}\right]\right]+ \\
& \left.+0,5 T_{a}\left[1-\exp \left(-2 t_{k} / T_{a}\right)\right]\right\} .
\end{aligned}
$$

In Table 3, for the case $T_{a}=50 \mathrm{~ms}\left(T_{p}=20 \mathrm{~ms}\right)$, the numerical values of the action integral $J_{C i A}$ calculated by (4) for the SC current $i_{k}(t)$ are given for the steady SC current amplitudes $I_{m k}$ and its durations (shutdown times) $t_{k}$ in power circuits of electrical equipment for general industrial use according to the requirements of $[4,8]$. Knowing the numerical values of the coefficient $D_{C i}$ (see Table 2) and the action integral $J_{C i A}$ of the SC current $i_{k}(t)$ (see Table 3), from (1) the numerical values of the critical sections $S_{C i}$ of the current-carrying parts of the considered $\mathrm{CCP}$ in power electrical installations circuits for general industrial use can be relatively easy determined. Taking into account the assumptions made, from the relation of the form $\delta_{C i} \approx I_{m k} / S_{C i}$, the critical amplitudes of the AC current densities $\delta_{C i}$ in the cores (shells) materials of the studied wires (cables) for the SC emergency fault mode can be quantified.

2.2. The results of the calculated choice of critical sections $S_{C i}$ and current densities $\delta_{C i}$ in wires and cables of electrical equipment circuits for general industrial purposes. Table 4 shows the results of approximate calculation according to (1), taking into 
Numerical values of the action integral $J_{C i A}$ for the SC current $i_{k}(t)$ flowing in power circuits of general-purpose electrical equipment $\left(T_{p}=20 \mathrm{~ms} ; T_{a}=50 \mathrm{~ms}\right)$ calculated by the relation (4)

\begin{tabular}{|c|c|c|}
\hline \multirow{2}{*}{$\begin{array}{c}\text { The value of the amplitude } I_{m k} \text { of } \\
\text { the steady SC current } i_{k}(t) \text { in the } \\
\text { power circuit of an industrial } \\
\text { electrical installation, kA }\end{array}$} & $\begin{array}{c}\text { Values of the action } \\
\text { integral } J_{C i A} \text { for the SC } \\
\text { current } i_{k}(t) \text { by }(4), \\
10^{7} \cdot \mathrm{A}^{2} \cdot \mathrm{s}\end{array}$ \\
\cline { 2 - 3 } & $t_{k}=100 \mathrm{~ms}$ & $t_{k}=160 \mathrm{~ms}$ \\
\hline 30 & 6.75 & 9.45 \\
\hline 50 & 18.75 & 26.25 \\
\hline 70 & 36.75 & 51.45 \\
\hline 100 & 75.00 & 105.00 \\
\hline 125 & 117.18 & 164.06 \\
\hline
\end{tabular}

account the data in Table 2, 3 of critical cross-sections $S_{C i}$ of copper (aluminum) cores (shells) of uninsulated (bare) wires and insulated wires (cables) of power circuits of general industrial electrical equipment $\left(T_{p}=20 \mathrm{~ms}\right)$ for the case when $J_{l i} \neq 0, t_{k}=100 \mathrm{~ms}$ and $T_{a}=50 \mathrm{~ms}$, and the amplitude $I_{m k}$ of the steady SC current $i_{k}(t)$ varies discretely in the range (30-100) kA. From the data of Table 4 it follows that the critical amplitudes of the densities $\delta_{C i} \approx I_{m k} / S_{C i}$ of the SC current $i_{k}(t)$ at the time of its flow (switch off) in the power circuits of electrical installations equal to $t_{k}=100 \mathrm{~ms}$ for uninsulated wires and insulated wires (cables) with PVC, R and PET insulation with copper (aluminum) cores (shells) in the circuits of electrical equipment for general industrial use $\left(T_{p}=20 \mathrm{~ms}\right.$; $T_{a}=50 \mathrm{~ms}$ ) are numerically approximately $1.57 \mathrm{kA} / \mathrm{mm}^{2}$ and $1.18 \mathrm{kA} / \mathrm{mm}^{2}$, respectively. It is important to note that these values of the critical amplitudes of the densities $\delta_{C i}$ of the SC current $i_{k}(t)$ in the materials of the currentcarrying parts of the wires (cables) of the power circuits of the electrical equipment do not depend on the level of the amplitude $I_{m k}$ of the steady SC emergency fault current of the power frequency of $50 \mathrm{~Hz}$.

Table 5 presents the results of the calculated determination according to (1), taking into account the data in Table 2, 3, of critical cross-sections $S_{C i}$ of copper (aluminum) cores (shells) of bare wires and insulated wires (cables) of power circuits of electrical equipment of general industrial use $\left(T_{p}=20 \mathrm{~ms}\right)$ for the case when $J_{l i} \neq 0, t_{k}=160$ ms and $T_{a}=50 \mathrm{~ms}$, and the amplitude $I_{m k}$ of the steady SC current $i_{k}(t)$ varies discretely in the range (30-100) kA.

Table 4

Numerical values of critical cross-sections $S_{C i}$ for bare wires and insulated wires (cables) with copper and aluminum cores (shells) in power circuits of general industrial electrical equipment with amplitude $I_{m k}$ of SC current $i_{k}(t)$ varying from 30 to $100 \mathrm{kA}$ (for $t_{k}=100 \mathrm{~ms}$ and $T_{a}=50 \mathrm{~ms}$ )

\begin{tabular}{|c|c|c|c|c|c|}
\hline \multirow{3}{*}{$\begin{array}{l}\text { Type of insulation } \\
\text { in the wire (cable) } \\
\text { of the electrical } \\
\text { installation }\end{array}$} & \multirow{3}{*}{$\begin{array}{l}\text { Material of the } \\
\text { core (shell) of } \\
\text { the wire (cable) }\end{array}$} & \multicolumn{4}{|c|}{ Values of section $S_{C i}, \mathrm{~mm}^{2}$} \\
\hline & & \multicolumn{4}{|c|}{$\begin{array}{l}\text { Amplitude } I_{m k} \text { of the } \\
\text { steady SC current, kA }\end{array}$} \\
\hline & & 30 & 50 & 70 & 100 \\
\hline \multirow{2}{*}{ Without insulation } & & 19.11 & 31.85 & 44.59 & 63.70 \\
\hline & & 25.38 & 42.31 & 59.24 & 84.63 \\
\hline \multirow{2}{*}{ PVC, R } & & 19.11 & 31.85 & 44.59 & 63.70 \\
\hline & Alu & 25.38 & 42.31 & 59.24 & 84.63 \\
\hline \multirow{2}{*}{ PET } & & 19.11 & 31.85 & 44.59 & 63.70 \\
\hline & Aluminum & 25.38 & 42.31 & 59.24 & 84.63 \\
\hline
\end{tabular}

Table 5

Numerical values of critical cross-sections $S_{C i}$ for bare wires and insulated wires (cables) with copper and aluminum cores

(shells) in power circuits of general industrial electrical equipment with amplitude $I_{m k}$ of SC current $i_{k}(t)$ varying from 30 to $100 \mathrm{kA}$ (for $t_{k}=160 \mathrm{~ms}$ and $T_{a}=50 \mathrm{~ms}$ )

\begin{tabular}{|c|c|c|c|c|c|}
\hline \multirow{3}{*}{$\begin{array}{l}\text { Type of insulation } \\
\text { in the wire (cable) } \\
\text { of the electrical } \\
\text { installation }\end{array}$} & \multirow{3}{*}{$\begin{array}{l}\text { Material of the } \\
\text { core (shell) of } \\
\text { the wire (cable) }\end{array}$} & \multicolumn{4}{|c|}{ Values of section $S_{C i}, \mathrm{~mm}^{2}$} \\
\hline & & \multicolumn{4}{|c|}{$\begin{array}{c}\text { Amplitude } I_{m k} \text { of the steady } \\
\text { SC current, kA }\end{array}$} \\
\hline & & 30 & 50 & 70 & 100 \\
\hline \multirow{2}{*}{$\begin{array}{l}\text { Without } \\
\text { insulation }\end{array}$} & & 22.61 & 37.68 & 52.76 & 75.37 \\
\hline & Alun & 30.04 & 50.06 & 70.09 & 100.13 \\
\hline \multirow{2}{*}{ PVC, R } & Copl & 22.61 & 37.68 & 52.76 & 75.37 \\
\hline & Alum & 30.04 & 50.06 & 70.09 & 100.13 \\
\hline \multirow{2}{*}{ PET } & Con & 22.61 & 37.68 & 52.76 & \begin{tabular}{|l|}
75.37 \\
\end{tabular} \\
\hline & Aluminum & 30.04 & 50.06 & 70.09 & 100.13 \\
\hline
\end{tabular}

From the data of Table 5 it follows that the critical amplitudes of the densities $\delta_{C i} \approx I_{m k} / S_{C i}$ of the SC current $i_{k}(t)$ at time $t_{k}=160 \mathrm{~ms}$ of its flow (switch off) in the power circuits of the electrical equipment under consideration for uninsulated wires and insulated wires (cables) with PVC, R and PET insulation with copper (aluminum) cores (shells) in the circuits of electrical equipment for general industrial use $\left(T_{p}=20 \mathrm{~ms} ; T_{a}=50 \mathrm{~ms}\right)$ numerically are approximately $1.33 \mathrm{kA} / \mathrm{mm}^{2}$ and $0.99 \mathrm{kA} / \mathrm{mm}^{2}$, respectively. Here, the numerical values of the critical amplitudes of the densities $\delta_{C i}$ of the SC current $i_{k}(t)$ in the copper (aluminum) cores (shells) of the CCP of the industrial electric power equipment under consideration, indicated for the calculation case $\left(t_{k}=160 \mathrm{~ms} ; T_{a}=50 \mathrm{~ms}\right)$, as well as for the previous case $\left(t_{k}=100 \mathrm{~ms} ; T_{a}=50 \mathrm{~ms}\right)$, do not depend on the quantitative values of the amplitude $I_{m k}$ of the steady SC current. In addition, from the data of Table 4, 5 it follows that the quantitative values of the critical cross-sections $S_{C i}$ and critical amplitudes of densities $\delta_{C i}$ of AC SC current $i_{k}(t)$ for the currentcarrying parts of the investigated $\mathrm{CCP}$, which is widely used in power circuits of electrical equipment of general industrial use, do not depend on any type of insulation (air or solid) used in the considered electric wires and cables of electric power devices.

\section{Conclusions.}

1. The proposed electrical engineering approach allows, according to the condition of the EE in the atmospheric air of the current-carrying parts of the CCP, to approximate the critical cross-sections $S_{C i}$ and the amplitudes of the densities $\delta_{C i}$ of the AC axial current for uninsulated wires with copper (aluminum) cores, as well as for insulated wires and cables with copper (aluminum) cores (shells), PVC, R and PET insulation, through which AC SC current $i_{k}(t)$ with given ATPs flows during emergency operation of power electrical equipment for general industrial use.

2. The used approximate calculation relations (1)-(4) made it possible for two real cases $\left(t_{k}=100 \mathrm{~ms} ; t_{k}=160 \mathrm{~ms}\right)$ at $T_{a}=50 \mathrm{~ms}$ to establish for a discrete change in the amplitude $I_{m k}$ of the steady SC current $i_{k}(t)$ in the range (30-100) kA specific capabilities of the proposed electrical engineering approach for the selection of critical sections $S_{C i}$ and density amplitudes $\delta_{C i}$ of AC current in 
the indicated wires and cables of power circuits of electrical equipment of general industrial use, in the current-carrying parts of which in emergency operating modes of the considered power electrical equipment large axial SC currents $i_{k}(t)$ flow.

3. It was established by calculation that the critical amplitudes of the densities $\delta_{C i} \approx I_{m k} / S_{C i}$ of the axial SC current $i_{k}(t)$ in copper (aluminum) cores of uninsulated wires and insulated wires (cables) with copper (aluminum) cores (shells), PVC, R and PET insulation at $T_{a}=50 \mathrm{~ms}$ for the case of switch off time $t_{k}=100 \mathrm{~ms}$ of the SC current $i_{k}(t)$ in the power circuits of electrical equipment numerically equal approximately $1.57(1.18) \mathrm{kA} / \mathrm{mm}^{2}$, and for a case of $t_{k}=160 \mathrm{~ms}-1.33(0.99) \mathrm{kA} / \mathrm{mm}^{2}$.

4. The results obtained for critical cross-sections $S_{C i}$ and density amplitudes $\delta_{C i}$ of $\mathrm{AC}$ axial current with frequency $f=50 \mathrm{~Hz}\left(T_{p}=20 \mathrm{~ms}\right)$ can be used in electric power practice to choice thermally resistant to large $\mathrm{SC}$ axial currents $i_{k}(t)$ the CCP with copper (aluminum) cores (shells), designed to operate in power circuits of electrical equipment of power industry.

\section{REFERENCES}

1. Baranov M.I. Calculation and experimental determination of critical sections of electric wires and cables in the circuits of devices of high-voltage high-current pulse technique. Electrical engineering \& electromechanics, 2019, no.2, pp. 39-46. doi: 10.20998/2074-272X.2019.2.06.

2. Knopfel' G. Sverkhsil'nye impul'snye magnitnye polia [Ultra strong pulsed magnetic fields]. Moscow, Mir Publ., 1972. 391 p. (Rus).

3. Baranov M.I. Izbrannye voprosy elektrofiziki. Monografiya $v$ 3kh tomakh. Tom 3: Teorija i praktika elektrofizicheskih zadach [Selected topics of Electrophysics. Monograph in 3 Vols. Vol. 3. Theory and practice of electrophysics tasks]. Kharkiv, Tochka Publ., 2014. 400 p. (Rus).

4. Orlov I.N. Elektrotehnicheskij spravochnik. Proizvodstvo $i$ raspredelenie elektricheskoj energii. Tom 3, Kn. 1 [Electrical engineering handbook. Production and distribution of electric energy. Vol. 3, Book 1. Ed. I.N. Orlov]. Moscow, Energoatomizdat Publ., 1988. 880 p. (Rus).

5. Belorussov N.I., Saakjan A.E., Jakovleva A.I. Elektricheskie kabeli, provoda i shnury. Spravochnik [Electrical cables, wires and cords. Directory]. Moscow, Energoatomizdat Publ., 1988. 536 p. (Rus).

6. Baranov M.I. A choice of sections of electric wires and cables in circuits of devices of high-voltage high-current impulse technique. Electrical engineering \& electromechanics, 2018, no.6, pp. 56-62. doi: 10.20998/2074-272X.2018.6.08.

7. Baranov M.I. Refined selection of allowable cross-sections of electrical conductors and cables in the power circuits of industrial electrical equipment taking into account emergency operating modes. Electrical engineering \& electromechanics, 2019, no.3, pp. 37-43. doi: 10.20998/2074-272X.2019.3.06.

8. Knyazevskyi B.A., Lipkin B.Yu. Elekrosnabzhenie promyschlennyh predpriyatij [Power supply of industrial enterprises]. Moscow, High School Publ., 1972. 432 p. (Rus).

Received 04.02.2019

M.I. Baranov, Doctor of Technical Science, Professor,

Scientific-\&-Research Planning-\&-Design Institute «Molniya», National Technical University «Kharkiv Polytechnic Institute», 47, Shevchenko Str., Kharkiv, 61013, Ukraine,

phone+38057 7076841, e-mail: baranovmi@kpi.kharkov.ua

\section{How to cite this article:}

Baranov M.I. A choice of critical sections of electric wires and cables in power circuits of electrical equipment of power industry. Electrical engineering \& electromechanics, 2019, no.5, pp. 35-39. doi: 10.20998/2074-272X.2019.5.06. 